\title{
Grey Clustering Approach to Assess Sediment Quality in a Watershed in Peru
}

\author{
Alexi Delgado $^{1}$, Jossel Altaminarano ${ }^{2}$, Luis Pariona ${ }^{3}$ \\ Patricia Oscanoa $^{4}$, Stephany Esquivel ${ }^{5}$, Wendy Mejía ${ }^{6}$, Chiara Carbajal ${ }^{7}$ \\ Mining Engineering Section, Pontificia Universidad Católica del Perú, Lima, Peru ${ }^{1}$ \\ Environmental Engineering Faculty, Universidad Nacional de Ingeniería, Lima, Peru² 3, 4, 5, 6 \\ Administration Program, Universidad de Ciencias y Humanidades, Lima, Peru ${ }^{7}$
}

\begin{abstract}
The evaluation of sediment quality is a relevant topic that involves the analysis of various parameters that are altered by natural or anthropogenic causes. Therefore, the Grey Clustering method provides an alternative to evaluate sediment quality. In the present study, the sediment quality of the Chontayacu river watershed was evaluated considering the results of the monitoring of twenty-three points carried out in the early evaluations by the Environmental Impact Evaluation Agency (OEFA by its Spanish acronym). These twenty-three points were separated into three blocks considering the monitoring points upstream of the Uchiza town center and the Chontayacu Alto and Chontayacu Bajo hydroelectric plants. Seven parameters were analyzed: $\mathrm{As}, \mathrm{Cd}, \mathrm{Cr}, \mathrm{Cu}, \mathrm{Pb}, \mathrm{Hg}$ and $\mathrm{Zn}$, which were compared with Canadian sediment quality standards for the protection of aquatic life. The results of the assessment showed that all points in the Chontayacu River were classified as having unlikely adverse biological effects from heavy metals. However, a quality ranking was established between the points of each block where it was found that points P3, P4 and P17 correspond to the lowest values for the high $\mathrm{CH}$, low $\mathrm{CH}$ and $\mathrm{CP}$ Uchiza blocks respectively. Finally, the results obtained will provide integrated information for decision making by the competent authorities in Peru, as well as indicate the level of sediment contamination that should be taken into account for the proposal of hydroelectric projects that influence sediment transport and entrainment.
\end{abstract}

\section{Keywords—Grey clustering; sediment quality; watershed}

\section{INTRODUCTION}

The Chontayacu River is a tributary of the left bank of the Huallaga River, belonging to one of the main basins of Peru due to its great water resource potential [1]. This river has potentially exploitable areas for hydroelectric purposes because there are no demands for water use, knowing that the few economic activities are limited to agriculture, livestock and forestry, therefore, the waters flow naturally without being exploited [2]. However, from an early evaluation of sediment quality, high concentrations of some heavy metals have been observed, which may be due to natural processes or anthropogenic factors [3].

The Chontayacu River originates in the eastern foothills of the Andes Mountains, above 4,000 m above sea level, flowing through the Aurecchico and Pumahuanunga Rivers, which converge at approximately 3,600 $\mathrm{m}$ above sea level, giving rise to the Chontayacu River up to the town of Uchiza, at 1,180 m above sea level. Along its course, the river receives contributions from numerous tributaries, the main ones being the Chonas, Lucmabamba and Frijol rivers on the right bank and Crisnejas on the left bank [4]. The sediment quality evaluation will be carried out from the upper part of the Santa Rosa de Oso hamlet to the jurisdiction of the Crisnejas hamlet (Blanco river), both belonging to the Chontayacu river basin.

During the development of the evaluation, the Grey Clustering method was used, which is mainly used to verify whether or not the study objects belong to predetermined classes so that they can be treated differently, i.e., classifying them according to their characteristics [5]. Therefore, the center-point triangular whitenization weight functions (CTWF) method was applied because it allows us to classify objects into definable classes, called Grey Classes [6].

Therefore, the specific objective of this study is to classify 23 points, divided into 3 major blocks of the Chontayacu River basin, based on Canadian Sediment quality levels for the protection of aquatic life [7], using the Grey Claustering method [15] based on triangular center-point whitening weighting functions (CTWF).

In the present study, Section II provides information on the literature reviewed. Section III details the CTWF method. Then, in Section IV, the case study is described, followed by the results and discussions in Section V. Finally, conclusions will be presented in Section VI.

\section{LITERATURE REVIEW}

Kejian and Min (2014) [9], applied the Grey Clustering method to evaluate the sediment quality of the coastal ocean of Jiangsu, central China. They established 3 grey clusters, between clean, low and high contamination for 39 coastal sediment samples. The evaluation results indicate that the surface sediment quality of the northern branch of the Yangtze River is comparatively better, while the quality of the abandoned yellow river mouth of Jiangsu province is the worst with the highest pollution. When analyzing the underlying reasons, pollutants discharged into the sea due to the increase of industrial and agricultural activities contributed to the pollution. Therefore, it is recommended to improve from the source to protect the marine ecosystem of the coastal area.

Delgado et al. (2017) [8], evaluated the water quality of the Santa river basin according to the parameters established by the Ministry of Environment in Peru, using the Grey Clustering method with triangular weight functions (CTWF). Monitoring 
data from the Peruvian National Water Authority of 2013 were used, where they analyzed twenty-one monitoring points in the Santa river basin. The results showed that $47.6 \%$ of the monitoring points presented good water quality for consumption by the population; 33.3\% moderate water quality for consumption by the population; and $19.1 \%$ of the points presented low water quality for consumption by the population. The gray grouping method showed interesting results and could be applied to other studies on water quality or environmental quality in general.

According to Quanz et al. (2020) [10], they conducted an ecological risk assessment (ERA) to determine the potential effect of human activities and industries within an aquatic ecosystem on sediments using the Canada-Ontario DecisionMaking Framework for Assessment of Great Lakes Contaminated Sediments (COA) method. Historical data (1996 to 2005) from South Baymouth were examined to determine contaminants of potential concern, especially bioaccumulative metals from a comparison with sediment quality standards (SQG). The results show that although the sediments presented negligible potential for ecological risk and did not require any remedial management action, this case study highlights the strengths of using COA for this IAS, but also highlights weaknesses that included unclear linkages between the cause and effects of aquatic contaminants.

\section{Methodology}

In this section we describe the Grey Clustering method [15] based on triangular center-point whitening weighting functions (CTWF), which has been used to evaluate sediment quality in the Chontayacu River, a tributary of the left bank of the Huallaga River [1], which is described as follows: first identify the monitoring points " $\mathrm{m}$ ", then define the sediment quality parameters "p" and finally define the Grey Classes "g", according to the sediment quality monitoring values. $x_{i j}=$ $(i=1,2, \ldots, m ; j=1,2, \ldots, p)$. The steps of the Grey Clustering method in CTWF [15] are presented in Fig. 1.

\section{Step 1: Determination of focal points}

The criteria ranges are divided into three grey classes and the center points are calculated based on the Canadian Sediment quality levels for aquatic life protection [7].

Step 2: Sizing of standard data and monitoring data

For the calculation of the dimensioned standard values, the parameters of the sediment quality "p" and the Grey Classes "g" are established, which form the following matrix $A=$ $[A i j ; i=1,2, \ldots, p ; j=1,2, \ldots, g]$; in that sense, it is normalized $(P i j)$ for each criterion. The normalized value is calculated by (1).

$P i j=\frac{\mathrm{A}_{\mathrm{ij}}}{\sum_{\mathrm{j}=1}^{\mathrm{S}} \mathrm{A}_{\mathrm{ij}} / g}$

For the calculation of the dimensioned monitoring data, the parameters of the sediment quality " $p$ " and the monitoring points " $\mathrm{m}$ " are established and form the following matrix $M=$ $[M i j ; i=1,2, \ldots, p ; j=1,2, \ldots, M]$, which is normalized (Kij) for each criterion. The normalized value is calculated by (2).
$K i j=\frac{M_{i j}}{\sum_{\mathrm{j}=1}^{\mathrm{g}} \mathrm{A}_{\mathrm{ij}} / g}$ values

Step 3: Determination of the triangular functions and their

The grey classes use as reference the Canadian Sediment quality levels for aquatic life protection [7], which gave us the data to measure the sediment quality in this research, these quality levels gives us 3 quality levels for each parameter so there will be 3 functions for each parameter. The new sequence of center points is $\lambda 1, \lambda 2$ and $\lambda 3$. For class $g=1,2$ and $3 ; j=1,2, \ldots, p$ for an observed value $x i j$. The calculation of the CTWF is shown using (3) (5); and Fig. 2 shows the plot of the triangular functions.

$f_{j}^{1}\left(x_{i j}\right)= \begin{cases}1, & x \in\left[0, \lambda_{j}^{1}\right] \\ \frac{\lambda_{j}^{2}-x}{\lambda_{j}^{2}-\lambda_{j}^{1}}, & x \in] \lambda_{j}^{1}, \lambda_{j}^{2}[ \\ 0, \quad x \in\left[\lambda_{j}^{2},+\infty[\right.\end{cases}$

$f_{j}^{2}\left(x_{i j}\right)=\left\{\begin{array}{l}\left.\left.\frac{x-\lambda_{j}^{1}}{\lambda_{j}^{2}-\lambda_{j}^{1}}, \quad x \in\right] \lambda_{j}^{1}, \lambda_{j}^{2}\right] \\ \left.\frac{\lambda_{j}^{2}-x}{\lambda_{j}^{2}-\lambda_{j}^{1}}, x \in\right] \lambda_{j}^{2}, \lambda_{j}^{3}[ \\ 0, x \in\left[0, \lambda_{j}^{1}\right] \cup\left[\lambda_{j}^{3},+\infty[\right.\end{array}\right.$

$f_{j}^{3}\left(x_{i j}\right)=\left\{\begin{array}{rr}\frac{x-\lambda_{j}^{2}}{\lambda_{j}^{3}-\lambda_{j}^{2}}, & x \in] \lambda_{j}^{2}, \lambda_{j}^{3}[ \\ 0, & x \in\left[0, \lambda_{j}^{2}\right] \\ 1, & x \in\left[\lambda_{j}^{3},+\infty[\right.\end{array}\right.$

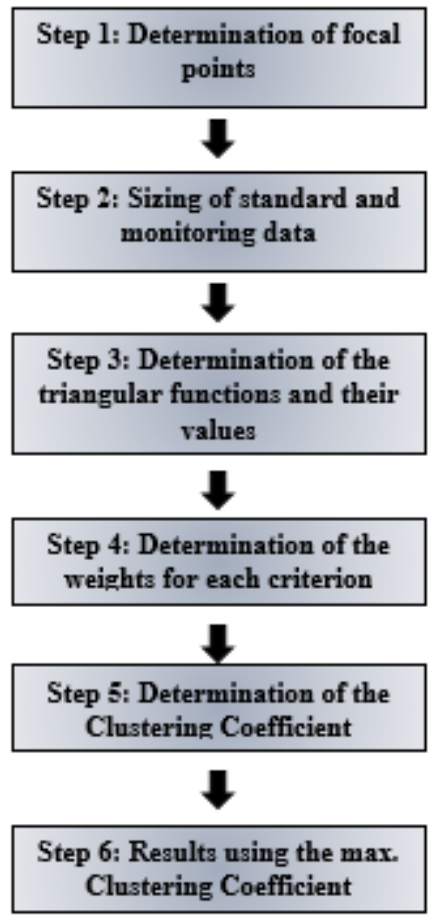

Fig. 1. Grey Clustering Method Diagram. 


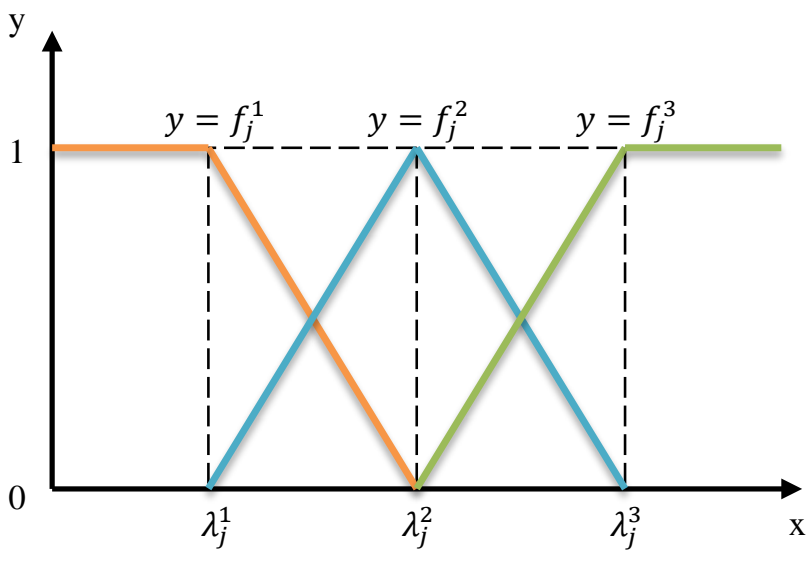

Fig. 2. Whitenization Functions.

Step 4: Determination of the weights for each criterion

The weights of each criterion known as Clustering weight (nij) is determined based on the dimensionless standard data, where Pij represents these, which were calculated in (1), to establish the values of nij will take into account the parameters of the sediment quality "p" and the Grey Classes "3" where $(i=1,2, \ldots, p ; j=1,2,3)$, the weights of each criterion are calculated by (6), as follows:

$\mathrm{n}_{\mathrm{ij}}=\frac{\frac{1}{\mathrm{P}_{\mathrm{ij}}}}{\sum_{\mathrm{x}=1}^{\mathrm{p}} \frac{1}{\mathrm{Pij}}}$

Step 5: Determination of the Clustering Coefficient

The values of the whitenization functions $\left(f_{j}^{g}\left(x_{i j}\right)\right)$ are determined by (3) - (5) and the weights of each parameter (nij) are calculated by (6). Once these calculations are defined, the Clustering coefficient is calculated by (7).

$\sigma_{j}^{g}=\sum_{j=1}^{p} f_{j}^{g}\left(x_{i j}\right) \times n_{i j}$

Step 6: Results using the max. Clustering Coefficient

With the results obtained in the previous step, the maximum values of each sampling point classified by blocks are selected, with which it is identified which areas contain unlikely, occasional or frequent biological effects; it is calculated by (8):

$\max \left\{\sigma_{i}^{g}\right\}=\sigma_{i}^{g^{*}}$

\section{CASE STUdy}

\section{A. Description of the Context}

The analysis of sediment quality was carried out in the Chontayacu River located in the micro-watershed of the Chontayacu River, belonging to the district of Cholon, province of Marañón, department of Huánuco. It is located in the upper basin of the Huallaga River, which has a total area of $89416 \mathrm{~km} 2$ in the northeastern part of Peru, on the Atlantic slope [1], being the main tributary of the most important basin in northern Peru, which is represented in Fig. 3.

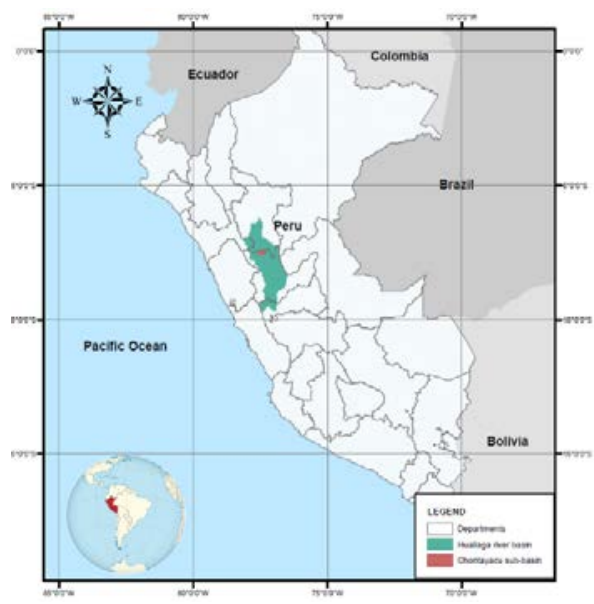

Fig. 3. Huallaga River Basin Location.

\section{B. Definition of Objects of Study}

For the evaluation of sediment quality in the upper Huallaga river basin, 23 points classified in three blocks (Upper Chontayacu Hydroelectric Plant, Lower Chontayacu Hydroelectric Plant and Uchiza Village Center), obtained from the early environmental assessment report on the future site of the upper and lower Chontayacu hydroelectric project and surrounding areas, in the district of Cholon, province of Marañón, department of Huánuco[3], were collected. These are detailed in Table I and represented in Fig. 4.

\section{Definition of Evaluation Criteria}

The evaluation criteria for the present study are determined by the Canadian Sediment Quality Standards for the Protection of Aquatic Life [7], which are presented in Table II.

\section{Definition of Grey Classes}

The Grey classes established for sediment quality assessment are three and are based on the Canadian Sediment quality levels for the protection of aquatic life [7], which are presented in Table III. 
TABLE I. MONITORING POINTS OF THE EARLy EVAluations CARRIED OUT By OEFA

\begin{tabular}{|c|c|c|c|c|c|}
\hline Block & Point & EAT Code & Description & This & North \\
\hline \multirow{3}{*}{$\begin{array}{l}\text { Central } \\
\text { Hydroelectric } \\
\text { Chontayacu } \\
\text { High } \\
\text { (CH-ALTO) }\end{array}$} & $\mathrm{P} 1$ & SED-RChon1 & $\begin{array}{l}\text { Point located on the left bank of the Chontayacu river, } \\
\text { approximately } 0.7 \text { km upstream from the confluence with the } \\
\text { Susto river and the Santa Rosa de Oso hamlet. }\end{array}$ & 311828 & 9047095 \\
\hline & P2 & SED-RSust1 & $\begin{array}{l}\text { Point located on the Susto river, approximately } 20 \text { m upstream } \\
\text { from the Susto bridge and } 100 \text { m before the confluence with the } \\
\text { Chontayacu river. }\end{array}$ & 312476 & 9047252 \\
\hline & P3 & SED-RChon2 & $\begin{array}{l}\text { Point located on the left bank of the Chontayacu River, } \\
\text { approximately } 0.5 \mathrm{~km} \text { before the confluence with the Oso River, } \\
\text { near the Santa Rosa de Oso hamlet. }\end{array}$ & 313311 & 9047400 \\
\hline \multirow{7}{*}{$\begin{array}{l}\text { Central } \\
\text { Hydroelectric } \\
\text { Chontayacu } \\
\text { Under } \\
\text { (CH-BAJO) }\end{array}$} & P4 & SED-RChon3 & $\begin{array}{l}\text { Point located on the left bank of the Chontayacu river, } \\
\text { approximately } 1 \mathrm{~km} \text { before the confluence with the Esperanza } \\
\text { river. }\end{array}$ & 314222 & 9047247 \\
\hline & P5 & SED-RChon4 & $\begin{array}{l}\text { Point located on the left bank of the Chontayacu river, } \\
\text { approximately } 950 \text { m before the confluence with the Aragán river. }\end{array}$ & 316141 & 9048347 \\
\hline & P6 & SED-RArag1 & $\begin{array}{l}\text { Point located on the Aragán river, approximately } 50 \text { m upstream } \\
\text { from the Aragán bridge and } 120 \text { m before the confluence with the } \\
\text { Chontayacu river. }\end{array}$ & 316987 & 9048655 \\
\hline & P7 & SED-RChon5 & $\begin{array}{l}\text { Point located on the left bank of the Chontayacu river, } \\
\text { approximately } 320 \text { m before the confluence with the Santillan } \\
\text { river. }\end{array}$ & 317794 & 9048774 \\
\hline & P8 & SED-RSanti1 & $\begin{array}{l}\text { Point located on the Santillan river, approximately } 50 \text { m upstream } \\
\text { from the Santillan bridge and } 250 \text { m before the confluence with } \\
\text { the Chontayacu river. }\end{array}$ & 318259 & 9048862 \\
\hline & P9 & SED-RYana1 & $\begin{array}{l}\text { Point located on the Yanajanca river, approximately } 250 \mathrm{~m} \text { before } \\
\text { the confluence with the Chontayacu river, near the Cocalito } \\
\text { hamlet. }\end{array}$ & 321126 & 9047235 \\
\hline & $\mathrm{P} 10$ & SED-RChon6 & $\begin{array}{l}\text { Point located on the Chontayacu river, near the Cocalito hamlet, } \\
\text { approximately } 200 \mathrm{~m} \text { before the confluence with the Yanajanca } \\
\text { river. }\end{array}$ & 321046 & 9047585 \\
\hline \multirow{13}{*}{$\begin{array}{l}\text { Center } \\
\text { Village } \\
\text { Uchiza } \\
\text { (CP-Uchiza) }\end{array}$} & P11 & SED-RChon7 & $\begin{array}{l}\text { Point located on the Chontayacu river, at the Nueva Galilea } \\
\text { hamlet, before the confluence with the Ollas river. }\end{array}$ & 323344 & 9047364 \\
\hline & P12 & SED-ROlla1 & $\begin{array}{l}\text { Point located approximately } 20 \mathrm{~m} \text { upstream from the Ollas bridge, } \\
\text { at the Nueva Galilea hamlet and before the confluence with the } \\
\text { Chontayacu river. }\end{array}$ & 323620 & 9047530 \\
\hline & $\mathrm{P} 13$ & SED-RSAna1 & $\begin{array}{l}\text { Point located on the Santa Ana river, approximately } 20 \mathrm{~m} \text { from the } \\
\text { Santa Ana bridge and } 100 \mathrm{~m} \text { before the confluence with the } \\
\text { Chontayacu river, at the Nueva Unión de Santa Ana hamlet. }\end{array}$ & 326359 & 9048903 \\
\hline & P14 & SED-RChon9 & $\begin{array}{l}\text { Point located on the left bank of the Chontayacu river, before the } \\
\text { confluence with the El Ají river, near the Nueva Unión de Ají } \\
\text { hamlet. }\end{array}$ & 327152 & 9049557 \\
\hline & P15 & SED-RPAle1 & $\begin{array}{l}\text { Point located on the Puerto Alegre river (Pólvora river), } \\
\text { approximately } 350 \text { m before the confluence with the Chontayacu } \\
\text { river and downstream of the Puerto Alegre bridge. }\end{array}$ & 329942 & 9051224 \\
\hline & P16 & SED-RChon10 & $\begin{array}{l}\text { Point located on the left bank of the Chontayacu river, } \\
\text { approximately } 2 \mathrm{~m} \text { from the Puerto Alegre bridge and } 500 \mathrm{~m} \\
\text { before the confluence with the Pólvora river. }\end{array}$ & 329085 & 9051345 \\
\hline & P17 & SED-RChon12 & $\begin{array}{l}\text { Point located on the left bank of the Chontayacu River, } \\
\text { approximately } 200 \text { m before the confluence with the San Antonio } \\
\text { River, near the San Antonio de Padua population center. }\end{array}$ & 330951 & 9051803 \\
\hline & P18 & SED-RChon13 & $\begin{array}{l}\text { Point located on the left bank of the Chontayacu river, } \\
\text { approximately } 200 \mathrm{~m} \text { before the confluence with the Camote river, } \\
\text { downstream of the San Antonio de Padua population center. }\end{array}$ & 332382 & 9053919 \\
\hline & P19 & SED-RChon14 & $\begin{array}{l}\text { Point located on the left bank of the Chontayacu river, } \\
\text { approximately } 200 \mathrm{~m} \text { after the confluence with the Blanco river, } \\
\text { near the Blanco river hamlet. }\end{array}$ & 332871 & 9054988 \\
\hline & P20 & SED-RChon15 & $\begin{array}{l}\text { Point located on the left bank of the Chontayacu river, } 100 \mathrm{~m} \\
\text { before the confluence with the Camote river, near the Crisnejas } \\
\text { Base of the Peruvian Army. }\end{array}$ & 333810 & 9055880 \\
\hline & P21 & SED-RCamo1 & $\begin{array}{l}\text { Point located on the Camote River, approximately } 500 \mathrm{~m} \text { before } \\
\text { the confluence with the Chontayacu River, at the Crisnejas Base of } \\
\text { the Peruvian Army. }\end{array}$ & 333544 & 9055269 \\
\hline & P22 & SED-RCamo2 & $\begin{array}{l}\text { Located on the Camote river, approximately } 300 \text { m before the } \\
\text { confluence with the Chontayacu river, near the Blanco river } \\
\text { hamlet. }\end{array}$ & 332617 & 9054011 \\
\hline & $\mathrm{P} 23$ & SED-RChon16 & $\begin{array}{l}\text { Point located on the Chontayacu river, approximately } 2 \mathrm{~km} \\
\text { downstream from the confluence with the Crisnejas river. }\end{array}$ & 335740 & 9056944 \\
\hline
\end{tabular}




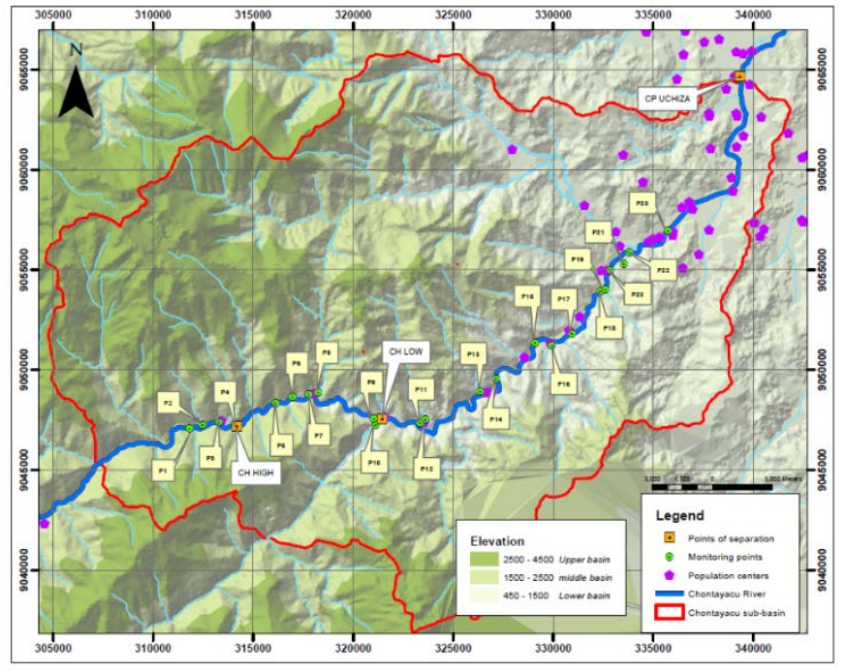

Fig. 4. Location of Sediment Quality Monitoring Points in the upper Huallaga River Basin.

TABLE II. EVALUATION CRITERIA FOR SEDIMENT QUALITY

\begin{tabular}{|l|l|l|}
\hline Notation & Criteria & Units \\
\hline C1 & As & $\mathrm{mg} / \mathrm{kg}$ \\
\hline C2 & $\mathrm{Cd}$ & $\mathrm{mg} / \mathrm{kg}$ \\
\hline C3 & $\mathrm{Cr}$ & $\mathrm{mg} / \mathrm{kg}$ \\
\hline C4 & $\mathrm{Cu}$ & $\mathrm{mg} / \mathrm{kg}$ \\
\hline C5 & $\mathrm{Pb}$ & $\mathrm{mg} / \mathrm{kg}$ \\
\hline C6 & $\mathrm{Hg}$ & $\mathrm{mg} / \mathrm{kg}$ \\
\hline C7 & $\mathrm{Zn}$ & $\mathrm{mg} / \mathrm{kg}$ \\
\hline
\end{tabular}

TABLE III. SEDIMENT QUALITY LEVELS FOR THE PROTECTION OF AQUATIC LIFE

\begin{tabular}{|l|l|l|l|}
\hline \multirow{2}{*}{ Criteria } & \multicolumn{3}{|l|}{ Biological effect } \\
\cline { 2 - 4 } & Unlikely & Occasional & Frequent \\
\hline $\mathrm{As}(\mathrm{mg} / \mathrm{kg})$ & 5.9 & $<5.9-17>$ & \\
\hline $\mathrm{Cd}(\mathrm{mg} / \mathrm{kg})$ & 0.6 & $<0.6-3.5>$ & 3.5 \\
\hline $\mathrm{Cr}(\mathrm{mg} / \mathrm{kg})$ & 37.3 & $<37.3-90>$ & \\
\hline $\mathrm{Cu}(\mathrm{mg} / \mathrm{kg})$ & 35.7 & $<35.7-197>$ & \\
\hline $\mathrm{Pb}(\mathrm{mg} / \mathrm{kg})$ & & $<35-91.3>$ & 91.3 \\
\hline $\mathrm{Hg}(\mathrm{mg} / \mathrm{kg})$ & 0.17 & $<0.17-0.486>$ & 0.486 \\
\hline $\mathrm{Zn}(\mathrm{mg} / \mathrm{kg})$ & & $<123-315>$ & \\
\hline
\end{tabular}

\section{E. Calculations using the CTWF Method}

The calculations for the case study based on the gray clustering method (CTWF) are shown below:

\section{Step 1: Determination of focal points}

Based on the Canadian Sediment quality levels for the protection of aquatic life [7], the central values of the parameters to be analyzed are obtained, which are presented in Table IV.

Step 2: Sizing of standard data and monitoring data

The dimensionless values of the standard data calculated for each criterion according to the Canadian Sediment Quality
Levels for the Protection of Aquatic Life [7] were determined through (1). These values are presented in Table V.

Similarly, based on data from the early environmental assessment report on the future site of the upper and lower Chontayacu hydroelectric project and surrounding areas, in the district of Cholon, province of Marañón, department of Huánuco (OEFA, 2017), the dimensioned values of the 23 monitoring points established for each criterion and separated by blocks were obtained using (2). These values are presented in Table VI. values

Step 3: Determination of the triangular functions and their

The triangular bleaching functions of the three grey classes for each parameter were obtained by replacing the values in Table IV in (3) - (5). As an example, the Clustering functions established for Arsenic are presented below.

$f_{j}^{1}\left\{\begin{array}{cc}1, & x \in[0,0.515] \\ \frac{1-x}{1-0.515}, & x \in[0.515,1] \\ 0, x \in[1,+\infty\rangle\end{array}\right.$

$f_{j}^{2}\left\{\begin{array}{c}\frac{x-0.515}{1-0.515}, \quad x \in[0.515,1\rangle \\ \frac{1.485-x}{1.485-1}, \quad x \in\langle 1,1.485\rangle \\ 0 \quad x \in[0,0.515] \cup[1.485,+\infty\rangle\end{array}\right.$

$f_{j}{ }^{3}\left\{\begin{array}{c}\frac{x-1}{1.485-1}, \quad x \in\langle 1,1.485\rangle \\ 1, \quad x \in[1.485,+\infty\rangle \\ 0, x \in[0,1]\end{array}\right.$

TABLE IV. CENTRAL VALUes of SEDIMENT Quality LEVELS FoR CANADA

\begin{tabular}{|c|c|c|c|}
\hline \multirow{2}{*}{ Criteria } & \multicolumn{3}{|c|}{ Biological effect } \\
\hline & Unlikely & Occasional & Frequent \\
\hline As (mg/kg) & 5.9 & 11.45 & \\
\hline $\mathrm{Cd}(\mathrm{mg} / \mathrm{kg})$ & 0.6 & 2.05 & 3.5 \\
\hline Cr (mg/kg) & 37.3 & 63.65 & \\
\hline $\mathrm{Cu}(\mathrm{mg} / \mathrm{kg})$ & 35.7 & 116.35 & \\
\hline $\mathrm{Pb}(\mathrm{mg} / \mathrm{kg})$ & & 63.15 & 91.3 \\
\hline $\mathrm{Hg}(\mathrm{mg} / \mathrm{kg})$ & 0.17 & 0.33 & 0.486 \\
\hline Zn (mg/kg) & & 219 & \\
\hline
\end{tabular}

TABLE V. STANDARD DimENSIONLESS VALUES OF SEDIMENT QUALITY LEVELS FOR CANADA

\begin{tabular}{|l|l|l|l|l|}
\hline Notation & Criteria & Unlikely & Occasional & Frequent \\
\hline C1 & As & 0.515 & 1 & 1.485 \\
\hline C2 & $\mathrm{Cd}$ & 0.293 & 1 & 1.707 \\
\hline C3 & $\mathrm{Cr}$ & 0.586 & 1 & 1.414 \\
\hline C4 & $\mathrm{Cu}$ & 0.307 & 1 & 1.693 \\
\hline C5 & $\mathrm{Pb}$ & 0.554 & 1 & 1.446 \\
\hline C6 & $\mathrm{Hg}$ & 0.518 & 1 & 1.482 \\
\hline C7 & $\mathrm{Zn}$ & 0.562 & 1 & 1.438 \\
\hline
\end{tabular}


TABLE VI. DIMENSIONED DATA OF THE MONITORING POINTS ESTABLISHED IN THE CASE STUDY

\begin{tabular}{|c|c|c|c|c|c|c|c|c|}
\hline \multirow{3}{*}{ Block } & \multirow{3}{*}{ Point } & \multicolumn{7}{|c|}{ Criteria } \\
\hline & & C1 & C2 & C3 & C4 & C5 & C6 & C7 \\
\hline & & As & $C d$ & $\mathrm{Cr}$ & $\mathrm{Cu}$ & $P b$ & $\mathrm{Hg}$ & $Z n$ \\
\hline \multirow{3}{*}{$\begin{array}{l}\text { Hydroelectric Power Plant } \\
\text { Chontayacu Alto }\end{array}$} & P1 & 2.62 & 2.54 & 0.70 & 0.15 & 0.00 & 22.99 & 0.34 \\
\hline & P2 & 0.44 & 1.79 & 0.30 & 0.17 & 0.00 & 15.00 & 0.27 \\
\hline & P3 & 2.18 & 3.08 & 0.76 & 0.17 & 0.00 & 29.15 & 0.34 \\
\hline \multirow{7}{*}{$\begin{array}{l}\text { Hydroelectric Power Plant } \\
\text { Lower Chontayacu }\end{array}$} & P4 & 2.18 & 2.87 & 0.77 & 0.17 & 0.00 & 34.45 & 0.37 \\
\hline & P5 & 1.83 & 2.70 & 0.72 & 0.18 & 0.00 & 31.71 & 0.35 \\
\hline & P6 & 0.03 & 2.45 & 0.31 & 0.36 & 0.00 & 22.96 & 0.37 \\
\hline & P7 & 1.83 & 2.75 & 0.76 & 0.15 & 0.00 & 26.04 & 0.36 \\
\hline & P8 & 0.03 & 1.15 & 0.06 & 0.05 & 0.00 & 13.63 & 0.20 \\
\hline & P9 & 2.18 & 0.13 & 0.54 & 0.19 & 0.00 & 29.30 & 0.40 \\
\hline & P10 & 2.45 & 0.09 & 0.69 & 0.20 & 0.00 & 30.40 & 0.37 \\
\hline \multirow{13}{*}{ Uchiza town center } & P11 & 1.66 & 0.09 & 0.50 & 0.15 & 0.00 & 22.47 & 0.31 \\
\hline & $\mathrm{P} 12$ & 0.16 & 0.02 & 0.05 & 0.02 & 0.00 & 27.87 & 0.26 \\
\hline & P13 & 0.06 & 0.02 & 0.03 & 0.03 & 0.00 & 20.06 & 0.18 \\
\hline & P14 & 1.92 & 0.08 & 0.63 & 0.20 & 0.00 & 26.95 & 0.36 \\
\hline & P15 & 0.17 & 0.08 & 0.06 & 0.02 & 0.00 & 46.34 & 0.13 \\
\hline & P16 & 2.45 & 0.12 & 0.62 & 0.21 & 0.00 & 31.40 & 0.41 \\
\hline & P17 & 2.36 & 0.14 & 0.69 & 0.23 & 0.00 & 34.76 & 0.45 \\
\hline & P18 & 2.01 & 0.09 & 0.59 & 0.19 & 0.00 & 29.42 & 0.37 \\
\hline & P19 & 2.01 & 0.07 & 0.58 & 0.17 & 0.00 & 24.39 & 0.34 \\
\hline & P20 & 1.48 & 0.05 & 0.47 & 0.15 & 0.00 & 24.91 & 0.30 \\
\hline & P21 & 0.14 & 0.03 & 0.08 & 0.04 & 0.00 & 27.41 & 0.11 \\
\hline & P22 & 0.11 & 0.02 & 0.04 & 0.02 & 0.00 & 20.03 & 0.11 \\
\hline & P23 & 2.18 & 0.08 & 0.59 & 0.20 & 0.00 & 30.49 & 0.36 \\
\hline
\end{tabular}

Step 4: Determination of the weights for each criterion

The values of the weights of each criterion evaluated were calculated using (6); the results are presented in Table VII.

\section{Step 5: Determination of the Clustering Coefficient}

The values of the clustering coefficients were calculated using (7) established in this study for the 23 monitoring points. The results of five monitoring points selected among the three blocks under study are presented in Table VIII.
Step 6: Results using the max. clustering coefficient

Finally, we selected the maximum values of the Clustering coefficients calculated using (8), with which we determined the biological effect presented by each monitoring point, which were separated by blocks, the results are presented in Tables IX, $\mathrm{X}$ and XI, where each maximum value was highlighted for its better appreciation.

TABLE VII. WEIGHTING OF EACH CRITERION EVALUATED IN THIS STUDY

\begin{tabular}{|l|l|l|l|l|}
\hline Notation & Criteria & Unlikely & Occasional & Frequent \\
\hline C1 & As & 0.123 & 0.143 & 0.146 \\
\hline C2 & Cd & 0.216 & 0.143 & 0.127 \\
\hline C3 & Cr & 0.108 & 0.143 & 0.153 \\
\hline C4 & $\mathrm{Cu}$ & 0.206 & 0.143 & 0.128 \\
\hline C5 & $\mathrm{Pb}$ & 0.114 & 0.143 & 0.150 \\
\hline C6 & $\mathrm{Hg}$ & 0.122 & 0.143 & 0.146 \\
\hline C7 & $\mathrm{Zn}$ & 0.112 & 0.143 & 0.151 \\
\hline
\end{tabular}


TABLE VIII. CLUSTERING COEFFICIENTS FOR FIVE MONITORING POINTS

\begin{tabular}{|c|c|c|c|c|c|c|c|c|c|c|}
\hline Block & Point & Criteria & C1 & $\mathrm{C2}$ & $\mathrm{C3}$ & C4 & C5 & C6 & C7 & Results \\
\hline \multirow{3}{*}{$\begin{array}{l}\text { Chontayacu Alto } \\
\text { Hydroelectric Power } \\
\text { Plant }\end{array}$} & \multirow{3}{*}{ P1 } & $f_{j}^{1}(\mathrm{X})$ & 0.00 & 0.00 & 0.72 & 1.00 & 1.00 & 0.00 & 1.00 & 0.510 \\
\hline & & $f_{j}^{2}(\mathrm{X})$ & 0.00 & 0.00 & 0.28 & 0.00 & 0.00 & 0.00 & 0.00 & 0.040 \\
\hline & & $f_{j}^{3}(\mathrm{X})$ & 1.00 & 1.00 & 0.00 & 0.00 & 0.00 & 1.00 & 0.00 & 0.419 \\
\hline \multirow{6}{*}{$\begin{array}{l}\text { Chontayacu Bajo } \\
\text { Hydroelectric Power } \\
\text { Plant }\end{array}$} & \multirow{3}{*}{ P4 } & $f_{j}^{1}(\mathrm{X})$ & 0.00 & 0.00 & 0.56 & 1.00 & 1.00 & 0.00 & 1.00 & 0.492 \\
\hline & & $f_{j}^{2}(\mathrm{X})$ & 0.00 & 0.00 & 0.44 & 0.00 & 0.00 & 0.00 & 0.00 & 0.063 \\
\hline & & $f_{j}^{3}(\mathrm{X})$ & 1.00 & 1.00 & 0.00 & 0.00 & 0.00 & 1.00 & 0.00 & 0.419 \\
\hline & \multirow{3}{*}{ P5 } & $f_{j}^{1}(\mathrm{X})$ & 0.00 & 0.00 & 0.67 & 1.00 & 1.00 & 0.00 & 1.00 & 0.505 \\
\hline & & $f_{j}^{2}(\mathrm{X})$ & 0.00 & 0.00 & 0.33 & 0.00 & 0.00 & 0.00 & 0.00 & 0.047 \\
\hline & & $f_{j}^{3}(\mathrm{X})$ & 1.00 & 1.00 & 0.00 & 0.00 & 0.00 & 1.00 & 0.00 & 0.419 \\
\hline \multirow{6}{*}{ Uchiza Village Center } & \multirow{3}{*}{ P12 } & $f_{j}^{1}(\mathrm{X})$ & 1.00 & 1.00 & 1.00 & 1.00 & 1.00 & 0.00 & 1.00 & 0.878 \\
\hline & & $f_{j}^{2}(\mathrm{X})$ & 0.00 & 0.00 & 0.00 & 0.00 & 0.00 & 0.00 & 0.00 & 0.000 \\
\hline & & $f_{j}^{3}(\mathrm{X})$ & 0.00 & 0.00 & 0.00 & 0.00 & 0.00 & 1.00 & 0.00 & 0.146 \\
\hline & \multirow{3}{*}{ P13 } & $f_{j}^{1}(\mathrm{X})$ & 1.00 & 1.00 & 1.00 & 1.00 & 1.00 & 0.00 & 1.00 & 0.878 \\
\hline & & $f_{j}^{2}(\mathrm{X})$ & 0.00 & 0.00 & 0.00 & 0.00 & 0.00 & 0.00 & 0.00 & 0.000 \\
\hline & & $f_{j}^{3}(\mathrm{X})$ & 0.00 & 0.00 & 0.00 & 0.00 & 0.00 & 1.00 & 0.00 & 0.146 \\
\hline
\end{tabular}

TABle iX. Results of the MaXimum Selected VAlue of the Clustering CoefFicient Calculations in the CH - Chontayacu Alto

\begin{tabular}{|l|l|l|l|}
\hline Chontayacu Alto Hydroelectric Power Plant & Occasional & Frequent \\
\hline Points & Unlikely & 0.000 & 0.273 \\
\hline P2 & 0.662 & 0.040 & 0.419 \\
\hline P1 & 0.510 & 0.060 & 0.419 \\
\hline P3 & 0.495 & & \\
\hline
\end{tabular}

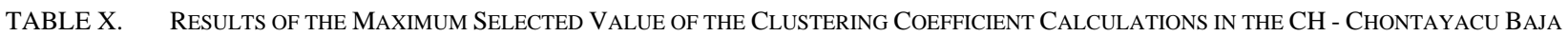

\begin{tabular}{|l|l|l|l|}
\hline Chontayacu Bajo Hydroelectric Power Plant & Occasional & Frequent \\
\hline Points & Unlikely & 0.000 & 0.292 \\
\hline P9 & 0.756 & 0.036 & 0.292 \\
\hline P10 & 0.728 & 0.174 & 0.174 \\
\hline P8 & 0.662 & 0.011 & 0.273 \\
\hline P6 & 0.646 & 0.047 & 0.419 \\
\hline P5 & 0.505 & 0.061 & 0.419 \\
\hline P7 & 0.494 & 0.063 & \\
\hline P4 & 0.492 & & 0.419 \\
\hline
\end{tabular}

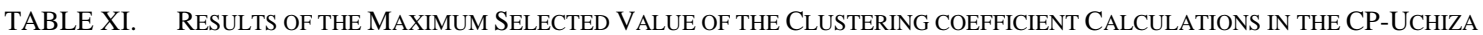

\begin{tabular}{|l|l|l|l|}
\hline Uchiza Village Center & Unlikely & Occasional & Frequent \\
\hline Points & 0.878 & 0.000 & 0.146 \\
\hline P12 & 0.878 & 0.000 & 0.146 \\
\hline P13 & 0.878 & 0.000 & 0.146 \\
\hline P15 & 0.878 & 0.000 & 0.146 \\
\hline P21 & 0.878 & 0.000 & 0.146 \\
\hline P22 & 0.756 & 0.000 & 0.292 \\
\hline P11 & 0.756 & 0.000 & 0.292 \\
\hline P19 & 0.756 & 0.000 & 0.292 \\
\hline P20 & 0.754 & 0.002 & 0.292 \\
\hline P18 & 0.754 & 0.002 & 0.292 \\
\hline P23 & 0.748 & 0.010 & \\
\hline P16 & 0.743 & 0.017 & 0.292 \\
\hline P14 & 0.728 & 0.037 & 0.292 \\
\hline P17 & & & \\
\hline
\end{tabular}




\section{RESUlTS AND DISCUSSION}

\section{A. About the Case Study}

Tables IX, X and XI show that the 23 points studied have a low probability of generating adverse biological effects to aquatic biota due to heavy metals for the three blocks established (CH-High, CH-Low and CP-Uchiza). In addition, we can point out that points P2, P9 and P12, which correspond to the highest values of clustering coefficients for the blocks $\mathrm{CH}$ High, $\mathrm{CH}$ Low and CP Uchiza respectively, represent very little bioavailability of heavy metals (As, $\mathrm{Zn}, \mathrm{Cu}, \mathrm{Cd}, \mathrm{Hg}, \mathrm{Pb}$, among others) [11] in sediments. On the contrary, points P3, P4 and P17 present the lowest clustering values for each block, giving them greater importance due to their environmental implications, which will be explained in Fig. 5, 6 and 7.

In relation to the results, we must pay attention to the $\mathrm{CP}$ Uchiza block because the Clustering coefficient values are the highest in that block compared to CH-High and Low, and also because it is near the Uchiza locality with a high density of inhabitants.

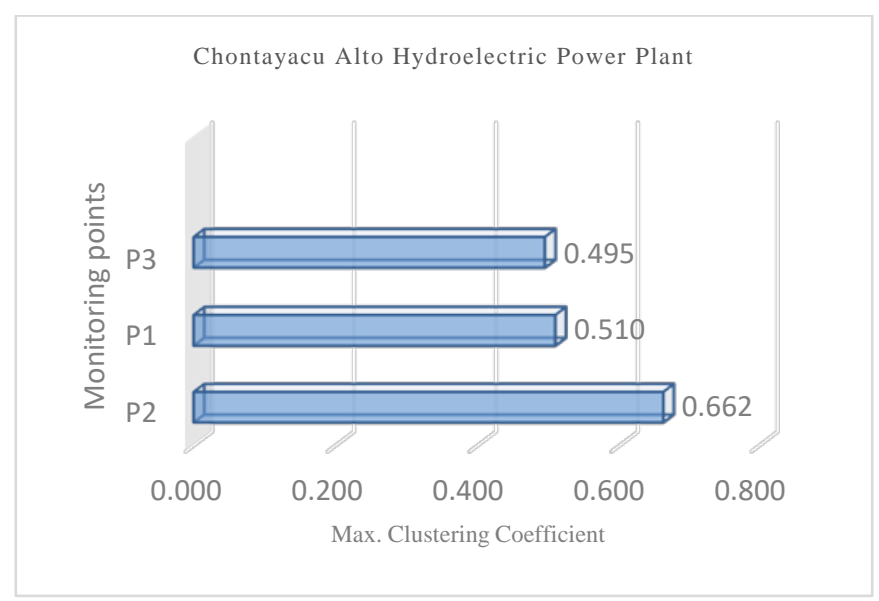

Fig. 5. Plot of Max. Monitoring Points for the Block (Chontayacu Alto Hydroelectric Power Plant).

According to Fig. 5, the following hierarchy is observed:

P2 > P1 > P3

Point P3 was sampled near the Santa Rosa de Oso hamlet, this population could have agricultural lands and pastures but upstream of their housing areas [12], which usually make use of fertilizers being a source of finding moderate and high concentrations of heavy metals such as $\mathrm{Pb}, \mathrm{Cr}, \mathrm{Zn}, \mathrm{As}$ and $\mathrm{Cd}$ in soils and sediments, which could affect points P1 and P2. As a result of the scarce natural vegetation in the study area [2], soils can release heavy metals that flow through runoff flows, either in particulate or dissolved form, and can accumulate in sediments downstream of the river [13].

In addition, points P1 and P2, which are located exactly on the Chontayacu River, receive water from the upper part of the basin, where there are about 13 population centers approximately $11 \mathrm{~km}$ away, which carry out subsistence activities such as livestock, forestry and agriculture [2]. Likewise, this zone has little to moderate precipitation. However, in order for there to be a greater accumulation of toxic elements such as heavy metals in the sediment due to their transport or dragging, it is necessary to have heavy precipitation, thus generating rainfall runoff, as suggested by some studies [14].

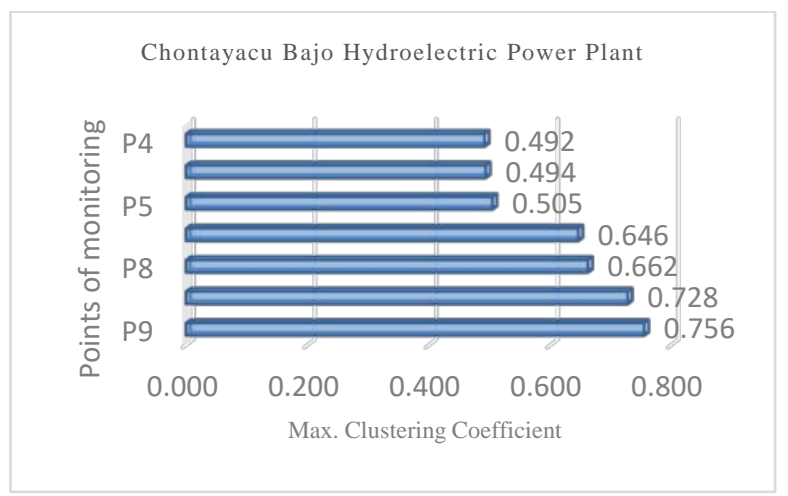

Fig. 6. Plot of Max. Monitoring Points for the Block (Chontayacu Bajo Hydroelectric Power Plant).

Fig. 6 shows the following hierarchy in relation to the clustering coefficient:

P9 > P10 > P8 > P6 > P5 > P7

Points P8, P9 and P10 show the highest values, mainly due to the increase in precipitation in the area [2], which removes deposited sediments and the presence of the Santillan and Cocalitos hamlets, respectively. These populations would be carrying out activities typical of the area, producing non-point sources of natural and anthropogenic origin that contribute to the increase in the concentration of heavy metals in sediments [3] at points P4 and P7. As part of the comprehensive ecological risk assessments in other rivers, the same problem of metal accumulation ( $\mathrm{Cu}, \mathrm{Pb}, \mathrm{Zn}, \mathrm{Cr}$ and $\mathrm{Cd}$ ) [15] has been observed in nearby areas and the ecological impact [16]on aquatic biota, especially on the river's benthic communities [17].

On the other hand, point P5 also has a low value and is located in an intermediate zone of anthropogenic areas (grazing areas, livestock and farming activities and agriculture [2]), it may be affected by the geomorphology of the basin, which has varied slopes that could drag or accumulate sediments[18]. Regard, it is important to note that sediment entrainment can increase during periods of floods and high precipitation, which, together with agricultural activities [19] reduce the concentrations of As, Cd, Zn, among other metals. However, moderate concentrations of heavy metals may also be due to natural processes such as erosion, biological activity and volcanic emissions [3].

According to Fig. 7, we observe the following hierarchy of the Clustering coefficient values: $\mathrm{P} 12=\mathrm{P} 13=\mathrm{P} 15=\mathrm{P} 21=\mathrm{P} 22>\mathrm{P} 11=\mathrm{P} 19=\mathrm{P} 20>\mathrm{P} 18=\mathrm{P} 23>\mathrm{P} 16>\mathrm{P} 14$
$>\mathrm{P} 17$

In relation to the present block, we observed that it is the most sensitive section due to the proximity to the Uchiza population center with a population of 21285 censused for the year 2017 [20]. Therefore, the bioaccumulation of heavy metals in fish and aquatic biota [21] should be carefully 
monitored due to sediment transport as a result of the increase in precipitation recorded in the Uchiza station, in addition this section has little slope which facilitates the disposal of sediments [2]. On the other hand, as the results indicate, there is very little probability of generating an adverse biological effect, this is due to the fact that the metals under study have been analyzed in an integrated manner, being found in the ranges of low to moderate biological contamination in the short term [22]. But the accumulated risk could exceed the acceptable levels of toxic elements over a longer period [21].

On the other hand, hydroelectric power plant reservoirs have serious sediment accumulation problems [23], and their cleaning and treatment is complicated by the accumulation of heavy metals [24], and if the upstream sediment flow is not properly managed. Then water outflows could affect the health of the aquatic ecosystem located downstream, and several ecotoxicological studies [25] on organisms, mainly fish, even endanger the health of nearby populations, such as those in the Uchiza population center.

On the other hand, the retention of solids produced by reservoirs, which mainly belong to hydroelectric projects, modifies the transport of nutrients and organic matter [26]. The reduction in the granulometry of suspended sediment and the modification of the water regime leads to the transport of fine sediments [27], which may include heavy metals or others, resulting in the armoring of the riverbed and a modification of the river habitat that may endanger aquatic life as well as the riverbeds.

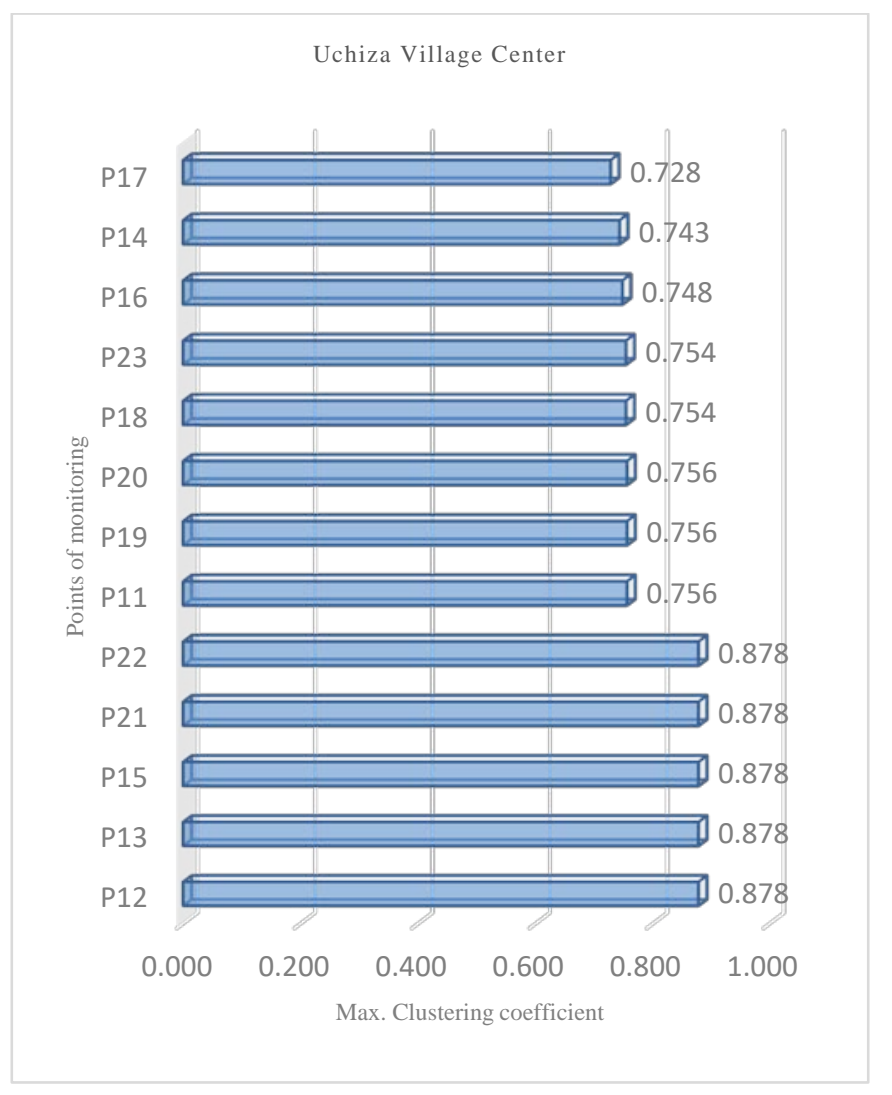

Fig. 7. Plot of Max. Monitoring Points for the Block (Centro Poblado Uchiza).
In relation to other studies [9], the Grey Clustering method was able to determine sediment quality in Jiangsu province, the results show serious contamination, pointing to the agricultural, energy and mining industries as the source of contamination.

\section{B. About the Methodology}

Unlike all the statistical methods that are traditionally used, Grey Clustering is a method that considers uncertainty in its analysis, which when performing the integration of the indicators in its evaluation; with respect to environmental pollution, it can be seen that there is a big problem regarding the high uncertainty presented in its different sources of pollution [28]. It can be evidenced that in the part of the contamination generated by the sediments produced by the different industrial activities [9], at the time of making their calculations they do not consider them synergistically, which indicates that their analysis is not the most appropriate. However, this method allows us to calculate in an appropriate way to classify and adequately evaluate the quality of sediments at an early stage of a project proposal.

\section{CONCLUSION}

Sediment quality in the Chontayacu river basin was evaluated using the Grey Clustering method, which classified the 23 monitoring points according to each separation block. The results obtained will provide integrated information for decision making by the competent Peruvian authorities, as well as indicate the level of sediment contamination that should be taken into account for the proposal of hydroelectric projects that influence sediment transport and entrainment.

There are few studies on the application of the Grey Clustering method for the early evaluation of sediments from quality standards. It turns out to be very effective because it integrates several contamination parameters, as well as the consideration of uncertainty within the analysis.

Finally, for future research, it is necessary to establish standard values for measuring sediment quality according to the geomorphology of each river in Peru, in order to improve the results of the Grey Clustering method. Likewise, research should be proposed to use the Grey Clustering method for sediment evaluation in areas with mining activities, hydrocarbons, large-scale agricultural activities and mainly in hydroelectric power plants, in order to measure the effectiveness of the method with respect to this environmental component.

\section{REFERENCES}

[1] Autoridad Nacional del Agua, "Informe de Monitoreo Participativo de la Calidad del Agua Superficial en la Cuenca del Río Huallaga - Febrero a Marzo del 2019”, Tarapoto, 2019. 2019.

[2] Hidroeléctricas Lima S.A., “'Estudio Hidrológico para la Acreditación de la Disponibilidad Hídrica Superficial del Río Chontayacu para el Proyecto Central Hidroeléctrica Chontayacu Bajo,’” 2015.

[3] Organismo de Evaluación y Fiscalización Ambiental, “'Informe de Evaluación Ambiental Temprana en el Futuro Emplazamiento del Proyecto Hidroeléctrico Chontayacu Alto y Bajo y Zonas Aledañas, en el distrito de Cholón, Provincia de Marañón, Departamento de Huánuco, durante el Año 2017,'” 2017.

[4] Servicio Nacional de Certificación Ambiental para las Inversiones Sostenibles, "Resolución Directoral № 175-2019-SENACE-PE/DEAR", "APROBAR el Estudio de Impacto Ambiental Detallado del Proyecto ‘Centrales Hidroeléctricas Chontayacu Alto y Chontayacu Bajo,’” 2019. 
[5] S. Liu, Y. Yang, and J. Forrest, Grey Clustering Evaluation Models. 2017.

[6] A. Delgado and I. Romero, "Applying the Grey Systems Theory to Assess Social Impact from an Energy Project," in Proceedings of the 2018 IEEE 25th International Conference on Electronics, Electrical Engineering and Computing, INTERCON 2018, 2018.

[7] Canadian Council of Ministers of the Environment, "Canadian Sediment Quality Guidelines for the Protection of Aquatic Life 'SUMMARY TABLES,” Environ. Conserv., 2002.

[8] A. Delgado and H. Flor, "Selection of the best air purifier system to urban houses using AHP," in 2017 CHILEAN Conference on Electrical, Electronics Engineering, Information and Communication Technologies, CHILECON 2017 - Proceedings 2017-January, pp. 1-4.

[9] K. J. Chu and M. Tan, "Assessment of sediment quality in jiangsu coastal ocean based on grey clustering method," Appl. Mech. Mater., vol. 535, pp. 266-271, 2014.

[10] M. Quanz, R. Willis, D. Burr, R. Recoskie, and T. R. Walker, “Aquatic ecological risk assessment frameworks in Canada: a case study using a single framework in South Baymouth, Ontario, Canada," Environ. Monit. Assess., vol. 192, no. 8, 2020.

[11] A. Sormunen, Bioavailability assessment of sediment-associated organic compounds through desorption and pore-water concentration. 2008.

[12] S. Helfgott, S. Vargas, A. C. Gutiérrez, and M. Salvatore, "Aptitud de tierras y oportunidades para el desarrollo rural en perú,” Bioenergia y Segur. Aliment. “BEFS,” pp. 25-36, 2010.

[13] M. De Siervi, A. F. De Iorio, and C. I. Chagas, "Heavy metals in sediments and runoff waters in soils of the Matanza river basin, Argentina," Commun. Soil Sci. Plant Anal., vol. 36, no. 17-18, pp. 2303-2314, 2005.

[14] H. Jeong, J. Y. Choi, J. Lee, J. Lim, and K. Ra, “Heavy metal pollution by road-deposited sediments and its contribution to total suspended solids in rainfall runoff from intensive industrial areas," Environ. Pollut., vol. 265, p. 115028, 2020.

[15] H. G. Hoang et al., "Heavy metal contamination trends in surface water and sediments of a river in a highly-industrialized region,” Environ. Technol. Innov., vol. 20, p. 101043, 2020.

[16] W. Ennaji, A. Barakat, M. El Baghdadi, and J. Rais, "Heavy metal contamination in agricultural soil and ecological risk assessment in the northeast area of Tadla plain, Morocco," J. Sediment. Environ., vol. 5, no. 3, pp. 307-320, 2020.
[17] R. B. Choueri et al., "Integrated sediment quality assessment in Paranaguá Estuarine System, Southern Brazil,” Ecotoxicol. Environ. Saf., vol. 72, no. 7, pp. 1824-1831, 2009.

[18] I. Pérez and L. Rumbo, "Evaluación de la capacidad de transporte de sedimentos en el Rio Tinaco, municipio Tinaco del Estado Cojedes," vol. Vol. 14 (2, 2017.

[19] A. Kabata-Pendias, "Soil-plant transfer of trace elements - An environmental issue,” Geoderma, vol. 122, no. 2-4 SPEC. IIS., pp. 143149, 2004.

[20] Instituto Nacional de Estadística e Informática, "Perú: Crecimiento y distribucion de la poblacion total, 2017. Poblacion censada más población omitida,” 2018.

[21] R. Fernandez-Maestre, B. Johnson-Restrepo, and J. Olivero-Verbel, "Heavy Metals in Sediments and Fish in the Caribbean Coast of Colombia: Assessing the Environmental Risk,” Int. J. Environ. Res., vol. 12, no. 3, pp. 289-301, 2018.

[22] N. S. Buzzi and J. E. Marcovecchio, "Heavy metal concentrations in sediments and in mussels from Argentinean coastal environments, South America,” Environ. Earth Sci., vol. 77, no. 8, pp. 1-13, 2018.

[23] Y. Huang, J. Wang, and M. Yang, "Unexpected sedimentation patterns upstream and downstream of the Three Gorges Reservoir: Future risks," Int. J. Sediment Res., vol. 34, no. 2, pp. 108-117, 2019.

[24] V. Angelaki and J. M. Harbor, "Impacts of flow diversion for small hydroelectric power plants on sediment transport, northwest washington,” Phys. Geogr., vol. 16, no. 5, pp. 432-443, 1995.

[25] A. Serafim et al., "Evaluation of sediment toxicity in different Portuguese estuaries: Ecological impact of metals and polycyclic aromatic hydrocarbons," Estuar. Coast. Shelf Sci., vol. 130, no. May, pp. 30-41, 2013.

[26] J. Ruiz Bellet, J. Balasch, and A. Tena, "Suspended sediment transfer during a flood along the dam-regulated Segre river (NE Iberian Peninsula),” Cuaternario y Geomorfol., vol. 25, no. 3, pp. 87-101, 2011.

[27] C. Guo, Z. Jin, L. Guo, J. Lu, S. Ren, and Y. Zhou, "On the cumulative dam impact in the upper Changjiang River: Streamflow and sediment load changes," Catena, vol. 184, no. September 2019, p. 104250, 2020.

[28] A. Delgado and I. Romero, "Environmental conflict analysis on a hydrocarbon exploration project using the Shannon entropy," in Proceedings of the 2017 Electronic Congress, E-CON UNI 2017, 2018January, pp. 1-4. 